\title{
Three New and Four Unrecorded Species of Chironomidae (Insecta: Diptera) in Korea
}

\author{
Han-II Ree* \\ Institute of Tropical Medicine \& Department of Environmental Medical Biology, \\ Yonsei University, Seoul 120-752, Korea
}

\begin{abstract}
Three new and four unrecorded species of Chironomidae (Insecta: Diptera) from Korea are described with illustrations. The genus Paracladopelma is reported for the first time in Korea.
\end{abstract}

Key words: new species, Chironomidae, Korea, taxanomy

\section{INTRODUCTION}

Adults of non-biting midges (Diptera: Chironomidae) which were collected by light traps, sweepings and/or aspiration on lights. They were preserved in $75 \%$ ethanol, and mounted on slide with either phenol-balsam or Hoyer's solution. They were identified under a high power microscope. As results, three new species and four unrecorded species in Korea were described with illustrations. Adding the present seven species, the fauna of Korean chironomidae consists of 88 species in 46 genera in 4 subfamilies. Terminology of Saether (1980) and Oliver and Dillon (1989) were followed.

The type specimens of three new species are deposited in the collection of Arthropods of Medical Importance Resource Bank, Department of Environmental Medical Biology, Yonsei University.

\section{SYSTEMATIC ACCOUNTS}

Subfamily Chironominae Macquart

Genus Paracladopelma Harnisch

1*Paracladopelma kisopediformis Sasa and Kondo, 1993 (Fig. 1A-C)

Paracladopelma kisopediformis Sasa and Kondo, 1993, p. 98.

Material examined. $60^{7} \sigma^{7}$ (R-CH-2739, 2742, 2743, 2744, 2751, 2755): Annam-myon, Okcheon-gun, Chungcheongbukdo, 3 Oct. 1986 (H.I. Ree).

Diagnosis. Small, brownish yellow midge. Wing length 1.8

*To whom correspondence should be addressed

Tel: 010-685-2530, Fax: 82-2-363-8676

E-mail: hanilree@naver.com mm. Superior volsella pediform, with an apical seta and densely covered with microtrichiae. Inferior volsella comprising round lobe extending along mesal margin of gonocoxite, covered with dense microtrichiae. Gonostylus basally fused with gonocoxite, slightly curved, with several short setae apically. AR 2.1.

Description (Male). HEAD: Eye black, bare, dorsomedial projection highly produced. Frontal tubercle small $(9 \times 6$ $\mu \mathrm{m})$. Antenna pale yellowish brown, with 11 segments, AR 2.1. Clypeus yellowish brown, with 14-15 setae. Palp yellowish brown (more or less pale), with 4 segments: 36,116 , $114,164 \mu \mathrm{m}(1: 3.2: 3.2: 4.6)$. THORAX: Ground color brownish yellow. Antepronolum narrow, notched dorsomedially. Scutum yellow; vittae not clear. Scutellum pale yellow, with 7-8 setae. Postnotum yellowish brown. WING (Fig. 1A): Membrane bare. All veins pale, without hairs. Wing length $1.8 \mathrm{~mm}$. Costa not produced. $R_{2+3}$ running near $R_{\perp}$ and ending well separated from ends of $R_{1}$ and $R_{4+5}$. $R M$ pale. $\mathrm{FCu}$ slightly distal to $\mathrm{RM}$. $\mathrm{Cu}_{1}$ almost straight. Anal lobe poorly developed. Squama with 2-3 weak setae. LEGS: Fore leg yellowish brown; basal half of tarsus I pale. Mid and hind legs all pale yellow, with slightly darker tips (tarsi IVV). Mid and hind tibiae with fused combs, bearing 2 spurs. Pulvillus developed. ABDOMEN: Uniformly yellowish brown. HYPOPYGIUM (Fig. 1B): Anal point slender, paralled-sided, weakly expanded distally. Ninth tergite posteriorly produced, with 9-13 setae near base of anal point. Superior volsella pediform, with an apical seta and densely covered with microtrichiae. Inferior volsella (Fig. 1C) comprising rounded lobe extending along mesal margin of gonocoxite, covered with dense microtrichiae. Gonostylus, basally fused with gonocoxite, weakly curved, with several short setae apically.

Remarks. Paracladopelma kisopediformis was described by 


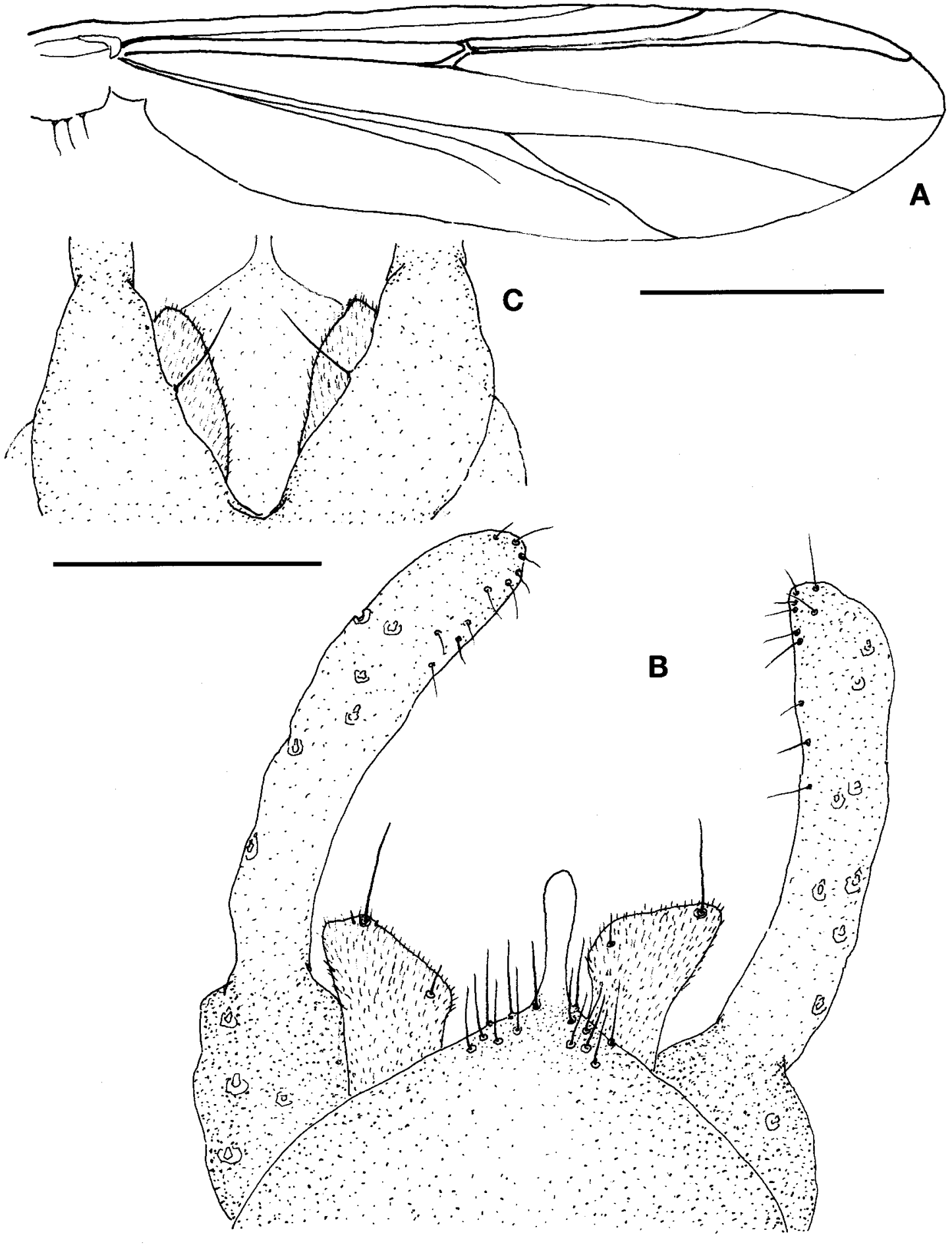

Fig. 1. Paracladopelma kisopediformis Sasa \& Kondo (Male). A, wing; $B$, hypopygium; C, inferior volsella (ventral view). Scale bars= $0.5 \mathrm{~mm}(A), 0.1 \mathrm{~mm}(B, C)$.

Sasa and Kondo (1993) with only one specimen collected in Toyama in November 1988. Six Korean specimens collected at Okcheon-gun, Chungcheongbuk-do in October 1986 well agreed with kisopediformis in all key characters. 
Genus Pentapedilum Kieffer

'*Pentapedilum nubens Edwards, 1929 (Fig. 2A, B)

Pentapedilum (Pentapedilum) nubens Edwards, 1929, p. 376;

Pinder, 1978, p. 134.

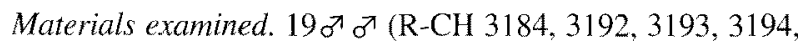
3208-3214, 3216-19, 3221-22, 3235-36); Byonsan beach, Buan-gun, Jeollabuk-do; 21 May 1993 (H.I. Ree).

Diagnosis. Small-medium, dark brown species. Wing length $2.2 \mathrm{~mm}$. Wing membrane and all veins heavily covered with macrotrichiae. AR 1.8. LR 1.2. Superior volsella digitiform apically hooked, without a lateral seta. Gonostylus very wide, slightly tapered apically, with one short apical and 6 lateral setae.

Description (Male). HEAD: Eye dark, bare, with dorso-medial projection. Antenna dark brown, with 13 flagellomeres (1st and 2nd segments almost fused); AR 1.8. Palp dark brown, with 4 segments: $79,151,144,216 \mu \mathrm{m}(1: 1.9: 1.8$ : 2.7). Clypeus brown, with $30-33$ segments. 6-9 postoculars and 7-8 orbitals. THORAX: vandike brown in ground color. Antepronotum dark brown, medially narrowly separated. Scutum slightly over-reaching antepronotum; inconspicuous vittae dark brown; 28-33 dorsocentrals and 7-10 prealars each side. Scutellum brown, with 22 setae. Postnotum dark brown. Halter pale dark brown. WING (Fig. 2A): Wing length 2.2 $\mathrm{mm}$. Membrane heavily hairy. All veins with hairs. Arculus and blachiolum pale dark brown, with 5 setae. Costa not produced. $R_{2+3}$ week, ending near end of $R_{1}$. FCu slightly distal to $\mathrm{RM}$. $\mathrm{Cu}_{1}$ almost straight. An very weak. Anal lobe moderately developed. Squama with 11-12 hairs. LEGS: Uniformly dark brown. LR 1.2. Fore tibia with a triangular spur; mid and hind tibiae each with broad, unspurred anterior comb and posterior narrow comb with an elongate spur. Pulvillus developed. ABDOMEN: All tergites dark brown, with unclear pale band along posterior margin. HYPOPYGIUM (Fig. 2B): Anal tergite apically produced. Anal point modelately long, natrowed basally. Superior volsella with 3-4 setosed base and apically hooked, digitiform extension, without a lateral seta. Median volsella absent. Inferior volsella parallel-sided, apically clubbed with a long, strong seta and 18-21 recurved setae. Gonostylus very wide, slightly tapered apically, with an apical and 6 lateral setae (not strong).

Remarks. Pentapedilum nubens was described as a new species by Edwards (1929) without illustration: body blackish, AR 1.5, LR 1.4 and wing length 2.5-3 mm. Pinder (1978) illustrated the hypopygium of nubens and described that superior volsella sickle-shaped without a lateral seta, which coincides with that of our specimens. Sasa and Suzuki(1995) reported Pentapedilum takarageheum sp. nov. with a full description with illustrations, which was related to $P$. nubens. Mein differences between nubens and takarageheum were (1) size and color of the body (wing length $2.5-3.0 \mathrm{~mm}$ vs 1.7-2.0 mm, and blackish vs brownish yellow), and (2) AR (1.5 vs 1.8). The Korean specimens are blackish (dark brown), wing length $2.2 \mathrm{~mm}$ and AR 1.8. These differences among European, Japan and Korean specimens would be treated as geographical variations. Other key characters of wings, legs, hypopygia and others are well coincided among them. Therefore, I treat our species as $P$. nubens which is the senior name.

\section{Genus Polypedilum Kieffer \\ ${ }^{2}$ Polypedilum leptovolsellae sp. nov. (Fig. 3A, B)}

Material examined. Holotype: 1 o (R-CH 2666), Wontong, Inje-gun, Gangwon-do; 2 Oct. 1988 (H.I. Ree), Paratypes: 1 o (R-CH 2665), 2 우우 (R-CH 2669, 2671), same data as holotype.

Diagnosis. Small, yellowish brown species. Wing length 1.5 $\mathrm{mm}$. Superior volsella pale, long, extremely narrow, abruptly curved apically, with several minute hairs at tip. Inferior volsella long, somewhat narrow, slightly expanded apically, with only 5-6 apical setae. AR 1.2. LR 1.95.

Description. Male. HEAD: Eye bare, dorsal projection highly developed; 7-8 postoculars. Frontal tubercle absent. Antenna with 13 segments; AR 1.2. Palp yellowish brown, with 4 segments: $20,29,71,80,114 \mu \mathrm{m}(1: 1.5: 3.6: 4: 5.7)$. Clypeus with 11 setae. THORAX: yellowish brown in ground color. Antepronotum yellowish brown, narrow, medially narrowly separated. Scutum brownish yellow; with inconspicuous brown vittae; 17 elected acrosticals, 9-10 dorsolaterals each side. Scutellum yellowish brown, with 6 setae. Postnotum brown. WING (Fig. 3A): Membrane bare. Only $\mathrm{R}, \mathrm{R}_{1}$ and distal half of $\mathrm{R}_{4+5}$ setosed. $\mathrm{R}_{2+3}$ ruming middle between $R_{1}$ and $R_{4+5}$ and ending well separated from end of $\mathrm{R}_{1}$. FCu well distal to RM. $\mathrm{Cu}_{1}$ slightly curved. An scaresly reaching $\mathrm{FCu}$. Anal lobe not developed. Squama with 3 setae. Wing length $1.5 \mathrm{~mm}$. LEGS: All segments brownish pale yellow, except slightly darker tarsi III-V of fore leg. Mid and hind tibiae with well separated two combs: inner comb unarmed and outer comb with a long spine. Pulvillus moderately developed. LR 1.95. ABDOMEN: Uniformly yellowish brown. HYPOPYGIUM (Fig. 3B): Posterior margin of tergite IX produced, with projections lateral to anal point. Anal point apically expanded slightly, heavily setosed at base. Superior volsella pale, long, extremely narrow, abruptly curved apically, with several minute hairs at tip. Inferior volsella long, somewhat narrow, slightly expanded at tip, with 5-6 apical setae. Gonostylus apically tapered, with an

\footnotetext{
1*뭉툭오각깔다구, ${ }^{2 *}$ 원틍무늬깔따구
} 

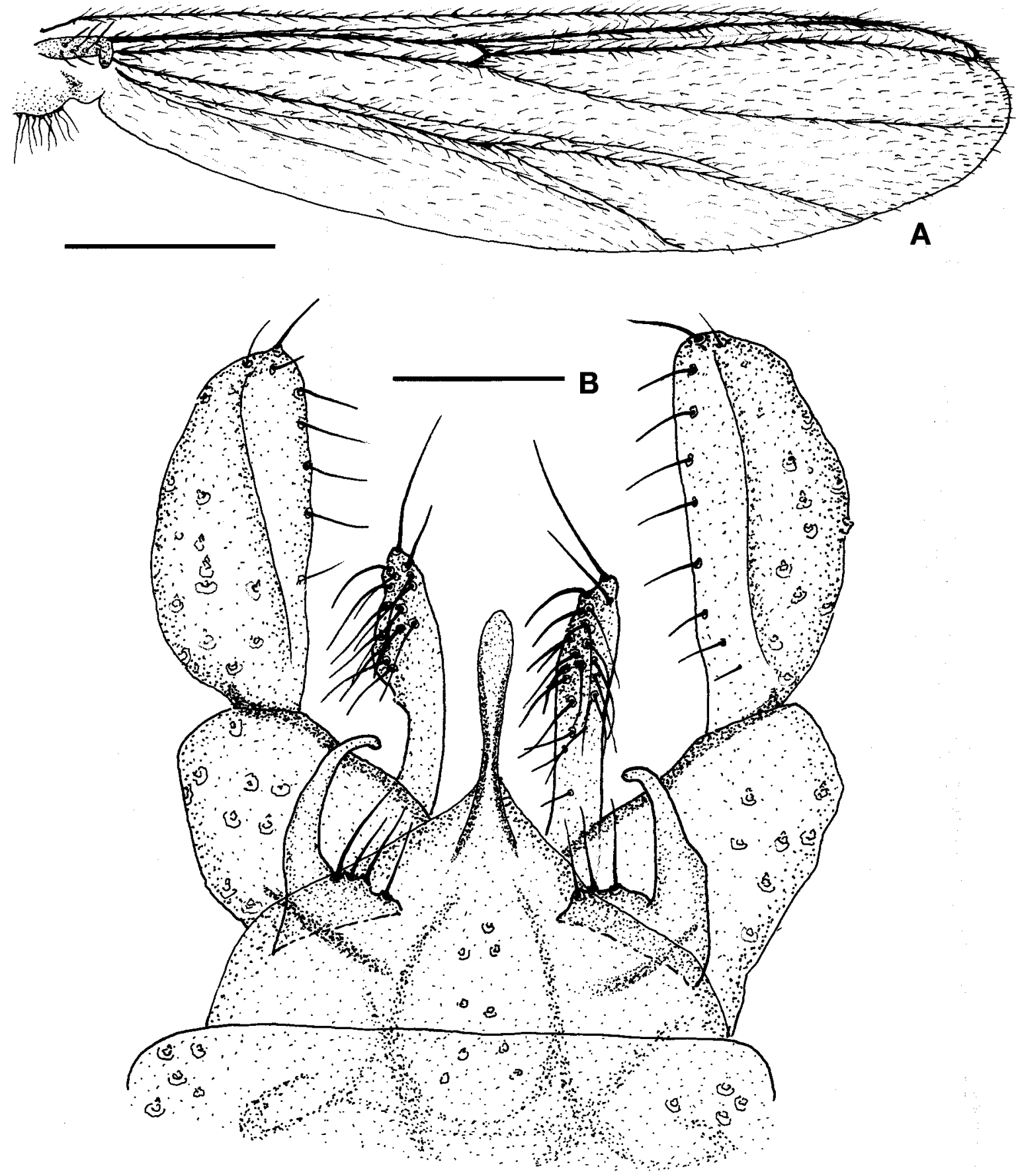

Fig. 2. Pentapedilum nubens Edwards (Male). $A$, wing; $B$, hypopygium. Scale bars=0.5 mm (A), $0.1 \mathrm{~mm}$ (B).

apical seta and 2 subapical setae.

Female. Generally same as in male, except usual sexual differences. Antenna yellowish brown, with 6 segments: $1: 1.7: 1.8: 1.9: 1.3: 3.3$. All leg segments uniformly pale yellow. Wing length $1.6 \mathrm{~mm}$.

Remarks. This new species belongs to subgenus Tripodula in the genus Polypedilum, as posterior margin of anal tergite (tergite IX) has a lobe (projection) on each side of the anal point. In most species of the subgenus Tripodula, superior volsella is broad and pad-like, whereas that of $P$. (T.) leptovolsellae $\mathbf{n}$. sp. is long, extremely narrow, and abruptly curved at tip, which is very unique. 


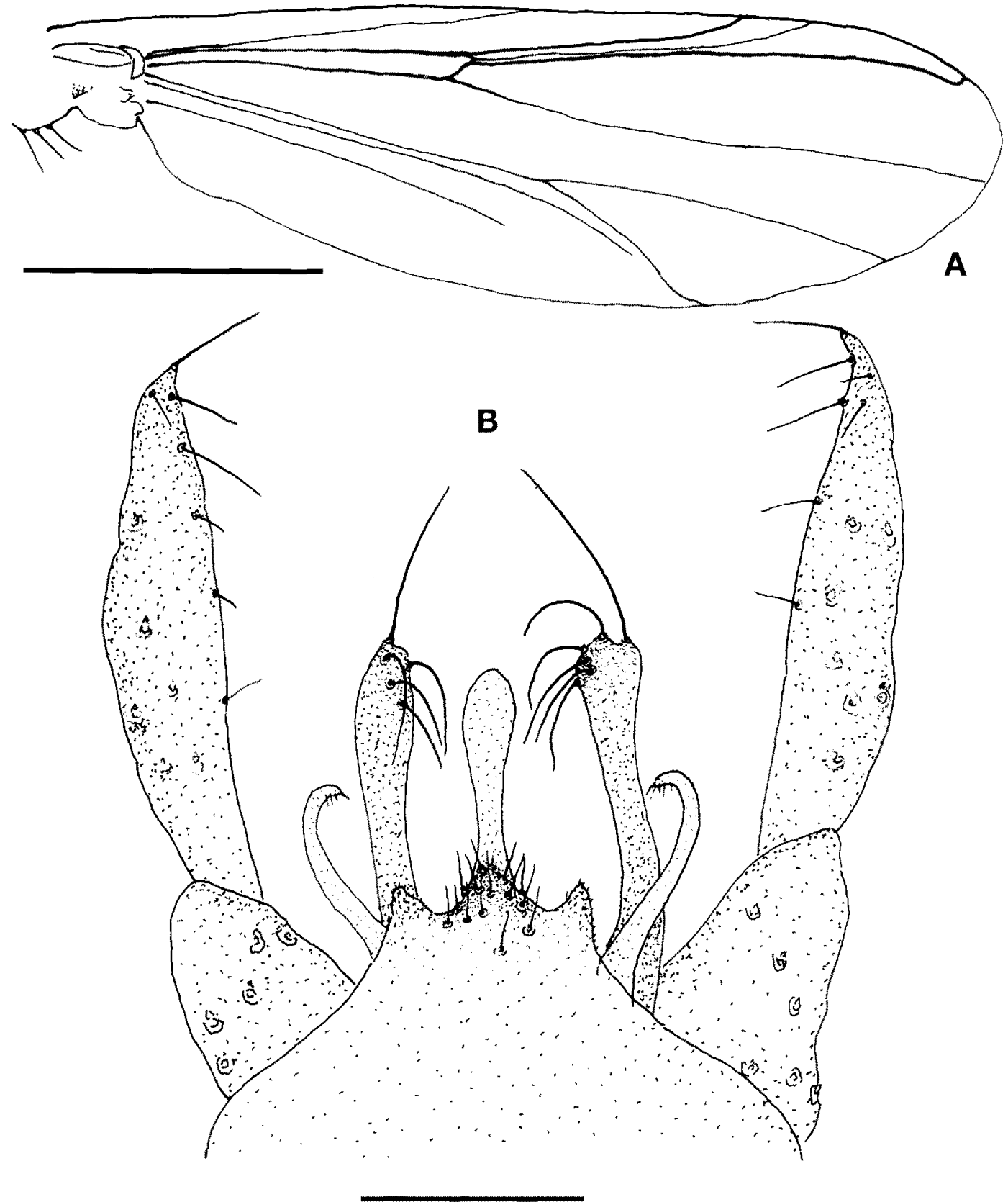

Fig. 3. Polypedilum leptovolsellae sp. nov. (Male). A, wing; B, hypopygium. Scale bars $=0.5 \mathrm{~mm}(\mathrm{~A}), 0.05 \mathrm{~mm}$ (B).

Genus Polypedilum Kieffer

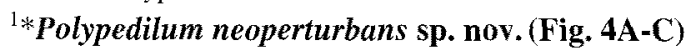

Material examined. Holotype: 18 (R-CH-367), Gure-eup, Gure-gun, Jeollanam-do; 2 Oct. 1977 (H.I. Ree). Paratypes: 3 우우 (R-CH 364, 369, 370), same data as holotype.

Diagnosis. small, brown species. Wing length $1.4 \mathrm{~mm}$. AR
1.1. LR 1.9. Superior volsella sylindrical, curved inwards, with an apical seta, a subapical seta, and a long lateral seta arising on distal $1 / 3$. Wing membrane with 10 distinct dark marks: 3 in cell $r_{4+5}, 2$ in cell $m_{1+2}, 2$ in cell $m_{3+4}$ and 3 in cell $\mathrm{cu}_{1}$.

Description. Male. HEAD: Eye black, bare, with dorso-medial projection. Antenna dark brown, with 13 flagellomeres;

**열무늬깔따구 

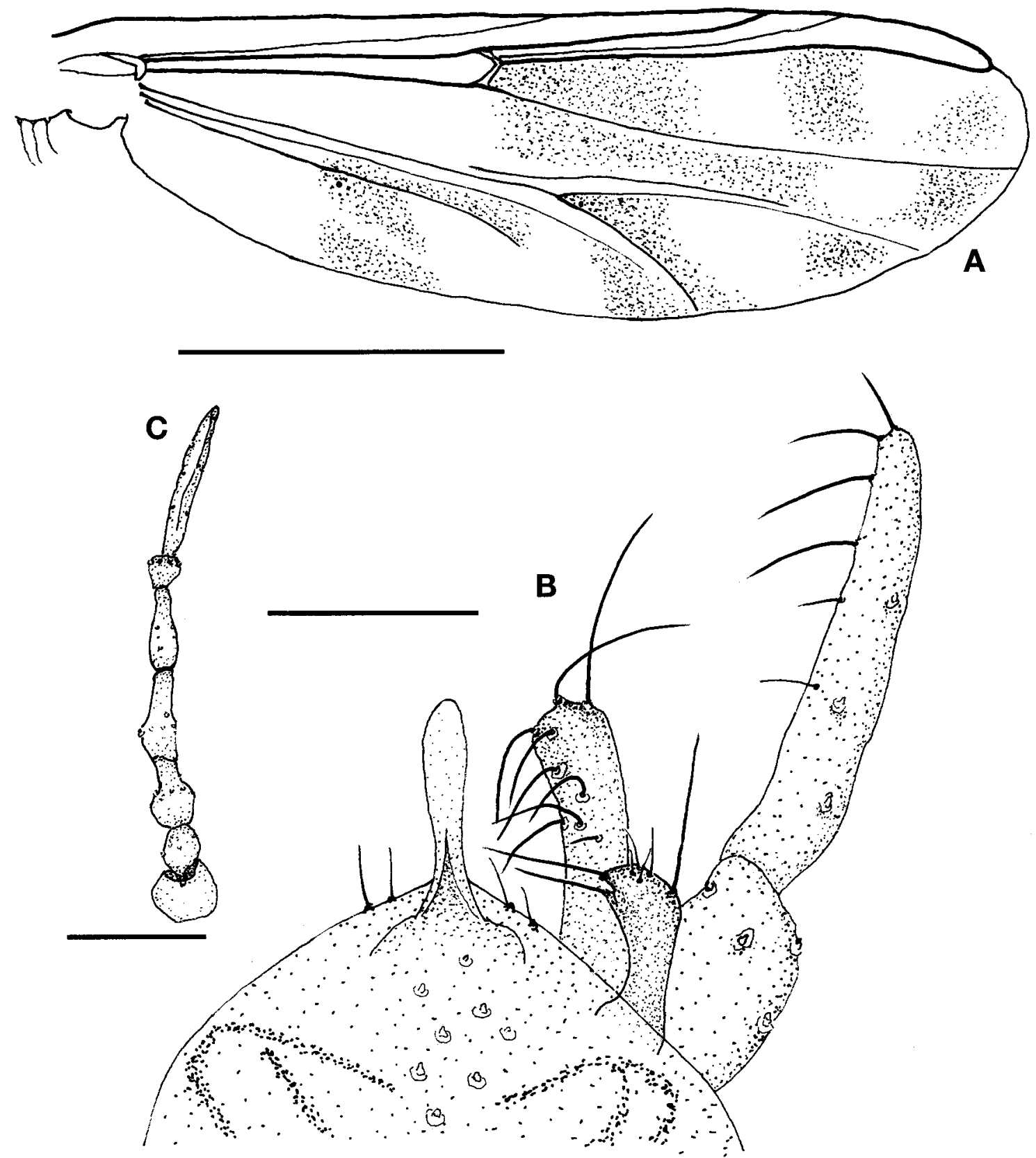

Fig. 4. Polypedilum neoperturbans sp. nov. (Male). A, wing; B, hypopygium; C, female antenna. Scale bars=0.5 mm (A), $0.05 \mathrm{~mm}$ (B), $0.03 \mathrm{~mm}$ (C).

AR 1.1. Clypeus brown, with 13 setae. Palp pale dark brown, with 5 segments: $25,32,57,50,93 \mu \mathrm{m}(1: 1.3: 3.0: 2.0$ : 3.7). THORAX: Brown in ground color. Antepronotum sharply narrowed dorsally and medially separated. Scutum well over reaching antepronotum; tubercle absent; slightly darker vittae obscure; 13 long acrosticlas and 10 long dorsomedials each side. Scutellum brown, with 9 setae on single line. Postnotum dark brown. Halter pale dark brown. WING (Fig. 4A):
Membrane bare, with 10 dark marks: 3 in cell $\mathbf{r}_{4+5}, 2$ in cell $\mathrm{m}_{1+2}, 2$ in cell $\mathrm{m}_{3+4}$, and 3 in cell $\mathrm{cu}_{1}$. Costa not produced. $\mathrm{R}_{2+3}$ ending near apex of $\mathrm{R}_{1}$. FCu slightly distal to $\mathrm{RM}$. $\mathrm{Cu}_{1}$ slightly curved. Anal lobe not developed. Squama with 3 setae. $\mathrm{R}, \mathrm{R}_{1}$ and distal half of $\mathrm{R}_{4+5}$ only setose. Wing length $1.4 \mathrm{~mm}$. LEGS: Trochantors and femurs yellowish brown. Tibiae brown on basal $3 / 4$ and rest yellow. Tarsus I pale brown with slightly darker proximal end; tarsus II pale (pro- 
ximal end of tarsus of hind leg darker); tarsi III-V pale brown. Mid and hind tibial combs with only one long spur. Pulvillus large. LR 1.9. ABDOMEN: Uniformly light brown. HYPOPYGIUM (Fig. 4B): Anal point moderately long (1.2 $\times 35.7 \mu \mathrm{m})$, apical end slightly expanded. Superior volsella more or less sylindrical, curved inwards, with apical and subapical setae (both long), and a log lateral seta arising on distal one-third. Inferior volsella sylindrical, slightly longer than anal point, with 8-9 setae on distal half portion. Gonostylus slender, apically rounded, with one apical, one subapical and two inner-lateral setae.

Female. Generally same as in male, except usual sexual differences. Antenna yellowish brown, 6 segmented as shown in Fig. 4C. Wing length $2.4 \mathrm{~mm}$.

Remarks. Kiefer (1921) reported the female of Microtendipes stictopterus as a new species, and a variation form of this species, Chironomus (Polypedilum) stictopterus var. perturbans n. var. was described by Johannsen (1932). Later, Tokunaga (1964) designated Polypedilum (Polypedilum) perturbans as a valid species. Polypedilum neoperturbans sp. nov. is similar to perturbans in general morphology, but has several different characters. The most important difference is superior volsella; that of perturbans is gradually tapered and curved at tip with fine hairs and bristles apically and one elongate terminal spine; whereas that of neoperturbans is not curved at tip without fine hairs and a terminal spine, but with 2 long apical setae, several hairs and one long subapical seta. Mid tibia of perturbans was yellow on basal $1 / 4$ and brown on rest, whereas that of this new species is brown on basal $2 / 3$ and yellowish on rest. Hater of the former was yellow, whereas that of the later is pale dark brown.

\section{Genus Polypedilum Kieffer}

\section{1*Polypedilum parviacumen Kawai and Sasa, 1985} (Fig. 5A, B)

Polypedilum parviacumen Kawai \& Sasa, 1985, p. 19-20; Sasa et al., 1988, p. 28.

Material examined. 7 व व (R-CH 2681, 2689, 2690, 2699, $2700,2701,2719), 2$ 우오 (R-CH 2685, 2686); Wontong, Inje-gun, Gangwon-do; 2 Oct. 1988 (H.I. Ree),

Diagnosis. Small brown species. Wing length $1.6 \mathrm{~mm}$. Anal point short, parallel-sided. Superior volsella rathre long, narrow, smoothly curved inward, with a relatively short lateral seta arising at basal 1/3; basal setae absent. AR 1.14. LR 1.72. Description. Male. HEAD: Eye bare, dark brown, with highly produced dorsomedial extension. 8-9 postoculars each side. Antenna dark brown, with 13 segments; AR 1.14. Palp pale dark brown, with 4 segments: $34,95,114,164 \mu \mathrm{m}(1: 2.8$ :
3.4 : 4.9). Clypeus with 16 setae. Frontal tubercle absent. THORAX: Ground color brown. Antepronotum dark brown, narrowed dorsally and medially separated. Scutum brown, with inconspicuous dark brown vittae; 15 acrosticals; 6 dorsocentrals each side. Scutellum dark brown, with 7 setae on single line. Postnotum dark brown. WING (Fig. 5A): Membrane bare. Wing length $1.6 \mathrm{~mm}$. Only vein $R, R_{1}$ and $R_{4+5}$ setose. Brachiolum pale with 1 seta. $R_{2+3}$ ending well separated from ends of $R_{1}$ and $R_{4+5}, 1 / 3$ near distance from $R_{1}$. $\mathrm{FCu}$ distal to $\mathrm{RM}$. $\mathrm{Cu}_{1}$ slightly curved (almost straight). Anal lobe poorly developed. Squama with 6 setae. LEGS: Uniformly yellowish light green. LR 1.72. Fore tibial scale somewhat triangular, with spinose apex; mid and hind tibiae with a long spine. Pulvillus not developed. ABDOMEN: yellowish pale brown; 6th-8th tergite slightly darker, with dark margin. HYPOPYGIUM (Fig. 5B): Posterior margin of 9 th tergite smoothly rounded, with numerous short, stout setae near base of anal point. Anal point short $(22 \mu \mathrm{m})$, narrow, paralled-side. Superior volsella rather long, narrow, smoothly curved inward, with a relatively short lateral seta $(25 \mu \mathrm{m})$, arising at about basal 1/3; basal setae absent. Inferior volsella cylindrical, slightly expanded apically with strong, incurved setae. Gonocoxite comparatively small. Gonostylus apically tapered, inter-lateral margin almost straight, with an apical and 2-3 inner-lateral setae.

Female. General characters same as in male, except usual sexual differences; abdomen slightly darker (light brown). Antenna with 5 segments; $1: 1.5: 1.7: 1.8: 3.9$. Wing length $1.5 \mathrm{~mm}$.

Remarks. The key characters of our speciemens well coincide with those of Polypedilum parviacumen described by Kawai and Sasa (1985) collected in Japan, except a minor difference. According to their description the setae on posterior margin of 9 th tergite were a little chitinized, whereas those of Korean specimens are not chitinized.

\section{Genus Xenochironomus Kieffer \\ 2*Xenochironomus hexataeniorhynchus sp. nov. (Fig. 6A-C)}

Material examined. Holotype: 1 व ( $\mathrm{RCH}-251)$, Ichon-dong, Yongsan-gu, Seoul; 20 Sept. 1977 (H.I. Ree). Paratype: 1 万 (RCH-252), same data as holotype.

Diagnoses. Medium sized, golden brown midge, Wing length $2.4 \mathrm{~mm}$. Scutum with 6 large, round, dark markings. Anal point very large and broad, strongly curved ventrally, with 7 strong setae dorsally. Superior volsella absent. Gonostylus rather slender, with several short apical setae. AR 2.7 . LR 1.6.

*작은꼬리무늬 깔딱. ${ }^{2}$ 등육점넓은포리깔따구 

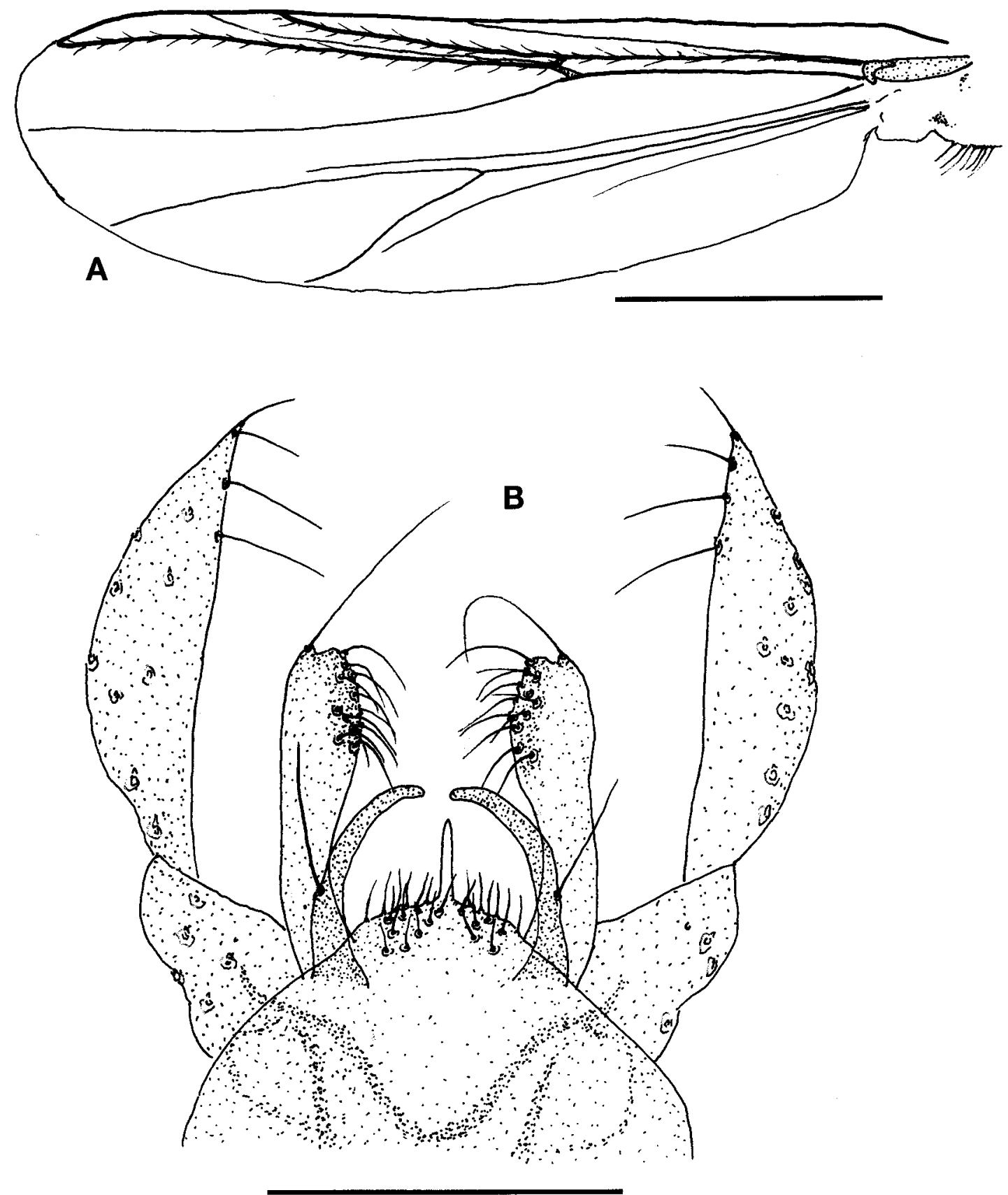

Fig. 5. Polypedilum parviacumen Kawai \& Sasa (Male). A, wing; $B$, hypopygium. Scale bars=0.5 mm (A), $0.1 \mathrm{~mm}(B)$.

Description (Male). HEAD: Eye black, bare, with dorsomedial paralle-sided elongation. Frontal tubercule absent. Antenna dark brown, with 11 segments; AR 2.7. Clypeus with $17-18$ setae on mostly upper half portion. Palp pale, 5 segmented: $50,30,207,150,214 \mu \mathrm{m}(1: 0.6: 4.2: 3: 4.3)$. THORAX: Uniformly, golden brown in groun color. Antepronotum dorsally seperated. Scutum with 6 large, round dark markings as shown in Fig. 6B; rather long, elected 33 acrosticlas arranged with 2 lines; 15-16 dorsocentrals each side; scutellum with 19-20 setae. Postnotum dark brown. WING (Fig. 6A): Wing length $2.4 \mathrm{~mm}$. Membrane bare. Costa not produced. $R_{2+3}$ ending midway between ends of $\mathrm{R}_{1}$ and $\mathrm{R}_{4+5}$. FCu distal to $\mathrm{RM}$. $\mathrm{R}$ and $\mathrm{R}_{1}$ only setose. $\mathrm{RM}$ not pigmented. $\mathrm{Cu}_{1}$ almost straight. Anal lobe moderately developed. Squama fringed. LEGS: Fore leg pale with tarsi III-V dark; mid and hind legs pale with distal half of tarsi 

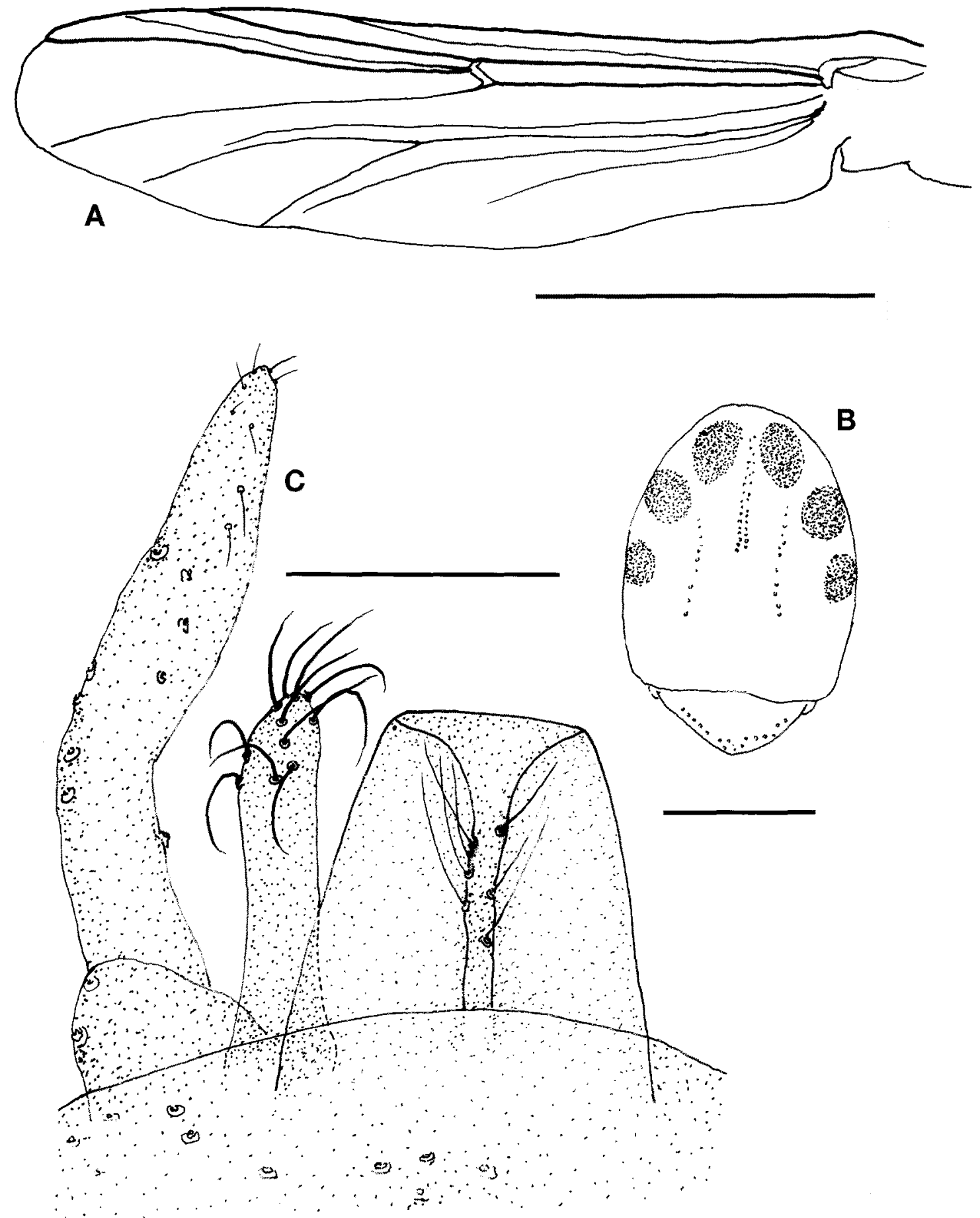

Fig. 6. Xenochironomus hexataeniorhynchus sp. nov. (Male). A, wing; B, Scutum and scutellum; C, hypopygium. Scale bars $=1.0 \mathrm{~mm}$ (A), $0.5 \mathrm{~mm}$ (B), $0.1 \mathrm{~mm}$ (C).

III, and IV-V dark. Apex of fore tibia with broad, rounded scales; mid and hind tibiae with slightly separated scales with 2 spurs. Pulvillus moderately developed. LEGS: All segments yellowish green, with slightly darker tips. Mid and hind tibiae with just separate combs, each with moderately long spur. Pulvillus normally developed. LR 1.6. ABDOMEN: Uniformly golden brown. HYPOPYGIUM (Fig. 6C): Anal point very large and broad, strongly curved 

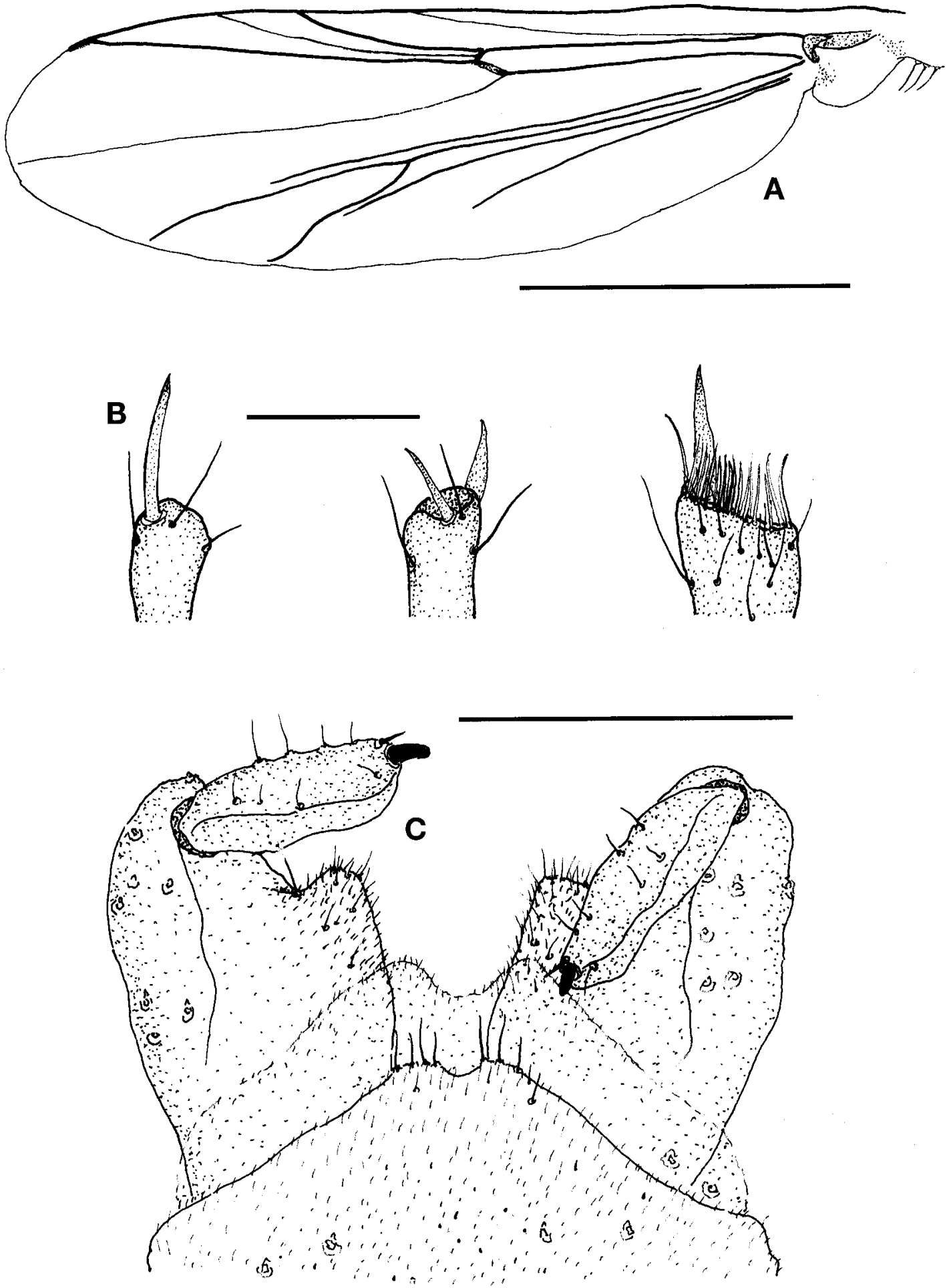

Fig. 7. Limnophyes tamakitanaides Sasa (Male). A, wing; B, apical end of tibia (fore, mid and hind from left); C, hypopygium. Scale bars $=0.5 \mathrm{~mm}(A), 0.05 \mathrm{~mm}(B), 0.1 \mathrm{~mm}(\mathrm{C})$.

ventrally, with 7 strong setae dorsally. Superior volsella absent. Inerior volsella slender, as long as anal point, with numerous long curved setae apically. Gonostylus slender, smoothly tapered apically, with several small apical setae. 
Remarks. Xenochironomus xenolabis (Kieffer) was added to the fauna of Korean chironomidae by Ree (2009), and this new species is the second species of this genus in Korea. $X$. hexataeniorhynchus has several unique characters which are easily distinguishable from other species, i.e. six black spots on scutum, extra large anal point, and absence of superior volsella.

Subfamily Orthocladiinae. Edwards.

Genus Limnophyes Eaton

${ }^{1}$ K Limnophyes tamakitanaides Sasa, 1981 (Fig. 7A-C)

Lymnophyes tamakitanaides Sasa, 1981, p. 97; Sasa, 1985 , p. 58; Sasa and Kawai, 1987, p. 46; Sasa, 1990, p. 46; Sasa and Okagawa, 1992, p. 142.

Material examined. $70^{7} \sigma^{7}$ (R-CH 3188, 3189, 3190, 3206, $3234,3237,3238)$ : Byonsan Beach, Buan-Gun, Jeollabukdo; 21 May 1993 (H.I. Ree).

Diagnosis. Small sized (Wing length $1.2 \mathrm{~mm}$ ), dark brown species. AR 0.76 . Ninth tergite with 2 small posterior lobes with several small setae. Inner lob of gonocoxite rather large with smoothly rounded margin. Tarsi IV and V of front and hind legs equal in length, mid tarsus IV shorter than V. LR 0.59 .

Description (Male). HEAD: Dark brown. Eye reniform, bare. Antenna dark brown, with 13 segments; AR 0.76. Palp pale dark brown, with 5 segments: $23,30,75,71,104 \mu \mathrm{m}(1: 1.3$ : $3.2: 3.1: 4.5$ ). Clypeus with 13 setae. THORAX: Dark brown in ground color. Antepronotum well developed, lobes separated anterior margin of scutum, with one dorsal seta and 2 lateral setae each side. Scutum dark brown; 8 lanceolate acrosticalls on posterior portion; 7 dorsocentrals each side; 6 prealars; 12 lanceolate supraalars. Scutellum brown with 6-7 uniserial scutellars. Postnotum dark brown. WING (Fig. 7A): Wing length $1.2 \mathrm{~mm}$. Membrane bare, with coarse punctuation (Microtrichiae visible at $100 \times$ magnification). Costa extended. $R_{2+3}$ running between $R_{1}$ and $R_{4+5} . R_{4+5}$ ending distal to end of $\mathrm{M}_{3+4}$. FCu well distal to $\mathrm{RM}$. $\mathrm{Cu}_{1}$ curbed at middle. An weekly developed. Anal lobe not developed (not produced). Squama with 2 setae. Brachiolum light brown, with one seta. Only vein $\mathrm{R}$ with a few setae basally; all other veins bare. LEGS: All segments uniformly brown. LR 0.59. Fore tibia with a long apical spur; mid tibia with 2 rather short terminal spurs; hind tibia with a large spur and a comb composed of 12-13 spurs (Fig. 7B). Pubillus absent. Front and hind tarsi IV and $V$ equal in length, but mid tarsus IV shorter than $V(46.4$ vs $57.1 \mu \mathrm{m})$. ABDOMEN: Uniformly light brown. HYPOPYGIUM (Fig, 7C): Anal point absent. Ninth tergite with two small postrior lobes, bearing several setae on each lobe. Inner lobe a gonocoxite rather large with smoothly rounded apically. Gonostylus simple, parallel-sided with a strong terminal spur and an apical seta.

Remarks. The Korean specimens are well coinsided with Japanese specimens of $L$. tamakitanaides described by Sasa (1981, 1985), except a few minor characters. The wing length of the Korean specimens is a little shorter than that of Japanese specimens ( $1.2 \mathrm{~mm}$ vs $1.4 \mathrm{~mm}$ ), and antepronotum of the former has one dorsal and 2 lateral settae, whereas that of the later with 2 dorsal and 2-6 lateral setae.

\section{ACKNOWLEDGEMENTS}

This study was supported by the fund for "Arthropods of Medical Importance Resource Bank, Korea".

\section{REFERENCES}

Edwards, F.W., 1929. British non-biting midges (Diptera, Chironomidae). Trans, R. Entomol. Soc. Lond., 77: 279-429.

Johannsen, O.A., 1932. Chironominae of the Malayan subregion of the Dutch East Indies. Arch. Hydrobiol. Suppl., 11: 503552.

Kawai, K. and M. Sasa, 1985. Seven new species of chironomid midges (Diptera, Chironomidae) from the Ohta River, Japan. Jap. J. Limnol, 46: 15-24.

Kieffer, J.J., 1921. Chironomides des Philippines et de Formose. Phil. J. Sci., 18: 557-593.

Oliver, D.R. and M.E. Dillon, 1989. The adult males of chironomidae (Diptera) of the Holarctic region. In the adult males of Chironomidae of the Holaretic Region-Keys and diagnosis (ed. Wiedercholm T.). Entomol. Scand. (Suppl.), 34: $11-15$.

Pinder, L.C.V., 1978. A key to adult males of British Chironomidae (Diptera), the non-biting midges. Freshwater Bio. Assoc. Sci. Publ., 37: 136-138.

Ree, H.I., 2009. One new and six unrecorded species of Chronomidae (Insecta, Diptera) in Korea. Korean J. Syst. Zool., 25: 49-59.

Saether, O.A., 1980. A glossary of chironomid morphology and terminology (Diptera: Chironomidae). Entomol. Scand. (Suppl.), 14: 1-51.

Sasa, M., 1981. Studies on chironomid midges of the Tama River. Part 3. Species of the subfamily Orthocladiinae recorded at the summer survey and their distribution to the pollntion with sewage waters. Res. Rep. NIES, 29:1-78.

Sasa, M., 1985. Studies on the chironomids collected from lakes in Southern Kyushu (Diptera, Chironomidae). Res. Rep. NIES, 83: 25-89.

Sasa, M. and S. Kondo, 1993. Additional chironomids recorded

1*갈색물깔따구 
from the middle reaches of Kiso River. Res. Rep. Toyama Pref. Envir. Poll., Part 7: 98-106.

Sasa, M. and H. Suzuki, 1995. The chironomid species collected on the Tokara Island, Kagoshima (Diptera). Jpn. J. Sanit. Zool., 46: 255-288.
Tokunaga, M., 1964. Diptera, Chironomidac. Insects Micronesia, 12(5): 485-628.

Received September 29, 2009 Accepted October 27, 2009 